\title{
Edirne Merkez Kreş ve Anaokullarına Kayıtlı 2-6 Yaş Grubu Çocukların Büyüme Gelişme Durumları ve Etkileyen Etmenler ${ }^{1}$
}

\author{
Sevim SARITEKINN ${ }^{1}$ ve Ilknur DINDAR ${ }^{2}$ \\ ${ }^{1}$ Aile ve Sosyal Politikalar Bakanlı̆̆ı, Edirne Huzurevi Müdürlüğ̈̈, Edirne, Türkiye, sevimnurse@hotmail.com \\ ${ }^{2}$ Trakya Üniversitesi, Sağlık Bilimleri Fakültesi Ayşekadın Yerleşkesi, Edirne, Türkiye
}

\begin{abstract}
Özet
Çalışma, Edirne il merkezinde bulunan kreş ve anaokullarına kayıtlı 2-6 yaş grubu çocukların büyüme gelişme durumlarını ve bu duruma etki eden etmenleri saptamak amaciyla, Edirne merkezindeki, kreş ve anaokullarına kayıtlı 417 çocuk ile tanımlayıcı ve kesitsel tipte planlandı. Bilgi formu ve çocuklardan alınan antropometrik ölçümler kullanılarak veriler toplandı. Araştırma grubu, yaş ortalaması $61.24 \pm 11.08$ ay, $\% 52.3$ 'u erkek ve \%39.0'1 61-72 ay arasinda olan kız çocuklardan oluştu. Ailelerin, \%89.7'si çekirdek aile tipinde ve \%60.0'1 tek çocuğu olduğu bulundu. Erkek çocuklarının anne sütü alma suresinin daha uzun $(\mathrm{p}<0.05)$ ve günlük öğün sayısının kız çocuklarına göre daha fazla olduğu saptandı $(\mathrm{p}<0.05)$. Çocukların vücut kitle indeksinin yoksulluk sınırının üstünde olan ailelerde anlamlı olarak yüksek olduğu bulundu $(p<0.05)$. Kız çocuklarının \%48.2'sinin, erkek çocuklarının ise \%50.9'unun boy değerlerinin ilk persentil çeyrekliğine yığıldığı görüldü. Ağırlık değerlerinde kız çocuklarının \%31.7'si 25. ve 50. persentil dilimlerinde, erkek çocuklarının ise \%28.4'ü 25. persentil ve altında idi. Çalışma grubundaki olguların sosyo-ekonomik durumları yüksekti. Dolayısıyla beslenme öyküleri de dahil olmak üzere tüm değişkenler olumlu bir görünüm sergilemekte idi.
\end{abstract}

Anahtar Kelimeler: 2-6 Yaş Grubu, Anaokulu Çocukları, Antropometri, Büyüme ve Gelişme.

\begin{abstract}
The study was registered to 417 child in baby nursery and kinder gardens with a descriptive and cross-sectional method in the center of Edirne to determine growth and development of children aged 2-6 and the factors affecting this stuation. The datas collected by information forms and the antropometric measures taken from the children. The research group was consist of the children that mean average of $61.24 \pm 11.08$ months and $52.3 \%$ of them were boys and $39.0 \%$ of them were girls. $89.7 \%$ of the families were in nuclear family type and $\% 60$ of them has only one child. The duration of the brast feeding period determined longer and the number of meals of boys determined more than the girls $(\mathrm{p}<0.05)$. Thats determined meaning fully greater in the families whose children's body mass index is higher from the destution border. $48.2 \%$ of the girls and $50.9 \%$ of boys lenght were accumulated in the first percentile. In weight measurements, $31.7 \%$ of girls were accumulated in 25 . and 50.th percentile and $28.4 \%$ of boys were accumulated in 25 .th percentile and below. The socio economic condition of the working group was high. Therefore, all of the variants including the feeding history were seemed positevely.
\end{abstract}

Keywords: 2-6 age group, Kindergarten children, Anthropometry, Growing up and development.

\footnotetext{
${ }^{1}$ 6. Ege Pediatri Günleri ve 2. Ege Pediatri Hemşireliği Günleri 2-5 Mayls 2012 Poster Bildiri olarak sunulmuştur.
} 


\section{Giriş}

Sağlığın temelleri çocukluk yıllarında atılmaktadır. $\mathrm{Bu}$ nedenle yarının erişkin toplumunu oluşturacak çocukların beyin ve vücut sağlığı ile çocukluk cağında ilgilenmek, mutlu ve sağlıklı bir toplum için gerekli ve akılcı bir yatırımdır. Çocukluk yıllarında oluşabilecek pek çok sağlık sorununa zamanında önlem alınmazsa ileriki yaşlarda önemlerini daha da arttırmaktadırlar (Akgün, 1997).

Sağlıklı çocuk, hastalık belirtileri göstermeyen, aynı zamanda kronolojik yaşına uygun bir vücut büyümesi, fizyolojik olgunlaşma, ruh ve zeka gelişimi gösteren çocuk olarak tanımlanır. Çocuğu erişkinden ayıran en önemli özellik, sürekli bir büyüme, gelişme ve değişme sureci içinde olmasıdır. Çocukta sağlık durumunu bozan durumlar büyüme ve gelişme surecini yavaşlatır, durdurur ya da normalden saptırır (Neyzi, 2002; Pekcan, 1984).

Gelişimin evrelerine bakıldığında; doğum öncesi ve doğum sonrası dönem olarak iki gruba ayrılır. Olumsuz cevre koşullarının en fazla etkilendiği kesim, büyümenin en hızlı ve dış etkilere en duyarlı olduğu dönem, yeni doğan ve ergenlik dönemi dahil olmak üzere tüm çocukluk dönemlerini kapsar. Bu yaşlarda karşılaşılan, çocukluk döneminde kötü beslenme, sık enfeksiyon geçirme gibi olumsuz durumlar, geriye dönüşsüz bozukluklarla sonuçlanabilir. $\mathrm{Bu}$ nedenle bu dönemlerde çocukların büyümelerinin düzenli aralıklarla izlenmesi ve değerlendirilmesi, çocukluk yaşlarında birçok hastalığın ilk belirtisi olan büyüme hızında azalmayı, büyüme ve gelişmede duraklamayı erken dönemde belirleyerek, gerekli önlemlerin alınmasını sağlamaktadır. Yaşa göre büyüme ve gelişme durumunun değerlendirilmesi, çocuk sağlığı izleminin önemli bir öğesidir (Neyzi, 2002). Çocukların gelişimlerinin izlenmesi, temel sağlık hizmetlerinin en önemli hizmetlerinden biridir. Sağlam çocukların izlenmesindeki amaç; sağlık durumlarının devamının sağlanması, hastalık, sakatlık ve ölümlerin azaltılması ve önlenmesidir (Evliyaoğlu, 2007)

Çocukların sağlık durumlarının değerlendirilmesinde en iyi gösterge büyümedir. Büyüme, genetik faktörlerin yanı sıra çevresel faktörlerden etkilenir. Yetersiz gıda alımı ve sık geçirilen enfeksiyonlar, gelişmekte olan birçok ülkede büyüme geriliğinin en önemli iki nedenidir. Çocuklarda normal büyüme ve gelişmenin bilinmesi, normal durumlarda sapmaların tanımlanması yoluyla hastalıkların belirlenmesi ve önlenmesi acısından gereklidir. İnsan organizmasının gelişimi çok geniş, karmaşık bir konudur, ancak altta yatan hastalığın tanınması ve tedavisi için, çocuklarla ilgilenen herkesin normal büyüme ve gelişme örüntüsünü bilmesi önemlidir, anormal değişimler böylece tanınabilir (Coşkun ve Aysun, 2003; Behrman ve Kliegmen, 2001).

Bir çocuğun fiziksel ve ruhsal sağlığını olumsuz etkileyen herhangi bir durum, çocuğun büyümesini ve gelişmesini durdurduğu için büyümenin düzenli olarak takip edilmesi gerekir. Başka bir deyişle büyümenin normal seyrinde devam etmesi en azından çocuğun sağlığını ciddi boyutta etkileyen bir sorunun olmadığını ifade eder (Ercan, 2003).

Büyüme ve gelişmenin en hızlı olduğu 0-6 yaş arası dönem, sağlıklı gelişimi olumsuz etkileyen çok sayıda etmene karşı oldukça duyarlı bir dönemdir. Bu olumsuz etmenlerden çok önemli biri de yetersiz ve dengesiz beslenmedir. Çocukların beslenmeleri, onların büyüme gelişmesini ve sağlığını direkt olarak etkilediği için bu dönemde çocukların sağlığının değerlendirilmesi, sağlıklı büyüme ve gelişimin sağlanması ve sürdürülmesi için gereklidir (Bertan ve Güler, 1997).

Antropometri, insan vücudunun bileşiminin, orantılarının ve tipinin ortaya konabileceği, evrensel olarak uygulanabilen, pahalı olmayan ve noninvaziv basit bir yöntemdir. Büyüme ve gelişmenin izlenerek bozuklukların erken dönemde saptanması amacıyla, vücut ağırlığı, boy uzunluğu, deri kıvrım kalınlığ1 (Triceps Skinfold-TSF) orta kol çevresi (Mid Arm Circumflex-MAC) gibi çeşitli antropometrik ölçümler kullanılmaktadır (Report of WHO Expert Comitte, 1995).

Değişen ve gelişen toplumsal yaşam koşulları karşısında aileler küçülmüş; kent yaşamı ana babanın ikisinin de çalışmasını gerektirir bir boyut kazanmıştır. Dolayısıyla gündüzleri okul öncesi çocuklarının bakılabileceği anaokulu, kreş gibi kurumlar doğmuştur. Bu kurumların çocukların sağlığı ile ne tur etkileşimler getirdiği çok sayıda araştırmaya konu oluşturmuştur (Saltık ve ark., 1990). Bu 
çalışmada amaç, Edirne merkezindeki kreş ve anaokullarına kayıtlı 2-6 yaş grubu çocukların, büyüme gelişme durumlarını belirleyerek, kurum çalışanlarına rehber oluşturmaktır.

\section{Gereç ve Yöntem}

Araştırma, Edirne il merkezinde bulunan kreş ve anaokullarına kayıtlı 2-6 yaş grubu çocukların büyüme gelişme durumlarını belirlemek ve bu duruma etki eden etmenleri saptamak amacıyla tanımlayıcı olarak planlandı.

Bu çalışmanın evrenini, Edirne merkezinde yer alan Milli Eğitim Müdürlüğü’ne (5 Anaokulu), Trakya Üniversitesi Rektörlüğü'ne (1 anaokulu) ve özel kreş ve anaokullarına (3 anaokulu ve kreş) Nisan 2009-Haziran 2009 tarihleri arasında kayıtlı olan 2-6 yaş grubu 598 okul öncesi çocuk oluşturdu (census). Araştırmaya, aileleri ve okul yetkilileri tarafından izin alınabilen 436 çocuk dahil edildi. Anket formlarına verilen eksik ve hatalı cevaplar nedeniyle formların 19'u değerlendirmeye alınamadı. Araştırma 417 çocuk ile tamamlandı.

Araştırma verilerinin toplanmasında, araştırıcı tarafından literatür bilgilerine dayalı olarak geliştirilen ve 51 sorudan oluşan anket formu ve araştırma kapsamına dahil edilen anaokulu çocuklarından alınan antropometrik ölçümler kullanıldı. Çocuklardan Antropometrik ölçüm olarak, boy uzunluğu, vücut ağırlığı, üst kol orta çevresi (ÜKOC), triceps deri kıvrım kalınlığı (TDKK) alındı. Ölçümler, araştırıcının kendisi tarafından ilgili anaokullarına gidilerek sınıf ortamında birebir gerçekleştirildi.

Kilo ölçümünde, çocukların kilolarını tam olarak tespit edebilmek ve oluşabilecek hatalara firsat vermemek için 100 gr hassasiyetli $150 \mathrm{~kg}$ kapasiteli elektronik baskül kullanıldı. Aletin ayarı belli aralıklarla kontrol edildi. Baskül düz ve sert bir zemine konulduktan sonra çocukların hareketsiz dik durumda ve karşıya bakar pozisyonda ölçümleri yapıldı. Ayrıca çocukların ölçüm sırasında sadece iç çamaşırları ile kalmaları sağlandı. Ölçümler gr olarak kaydedildi.

Çocukların olan boy uzunluklarının tespitinde elektronik boy ölcüm aleti kullanıldı. Boy ölçümleri sırasında ayakkabıları çıkarılan öğrencilerin topuk arkaları, sırtları, omuzları ve başlarının arkası duvara bitişik olacak şekilde durmaları sağlandı ve elektronik boy ölçerin çubuğu baş üzerinde sabitlenerek boy ölçüldü. Ayrıca ölçümler sırasında çocukların baş, göz ve kulak deliklerinin yere paralel olacak şekilde dik durumda olmaları sağlandı. Ölçümler cm olarak kaydedildi.

ÜKOC ölçümleri bütün çocuklarda aynı mezura kullanılarak, sol koldan yapıldı. Çocuğun sol kolu dirsek ekleminden fleksiyona getirildi. Omuzda akramion ile dirsekte olekranon arasındaki mesafe ölçüldü. Bu iki çıkıntı arasındaki orta nokta işaretlendi. Kol dirsek ekleminden ekstansiyona getirildi ve işaretlenen orta noktadan mezura çok s1kı veya gevşek olmayacak şekilde yerleştirilerek ölçüm yapıldı ve $\mathrm{cm}$ olarak kaydedildi.

TDKK ölçümleri skinfold caliper ile yapıldı. Sol kolun orta noktası işaretlendikten sonra, cilt ve cilt altı dokusu kas tabakasından ayrılarak, iki parmağın arasına alınan kısım cihazla mm cinsinden ölçüldü. Yaş tespitinde okullardaki kayıtlar esas alındı. Yaş hesaplanırken ölçümlerin yapıldığı tarihten doğum tarihi çıkarıldı. Yaşın ay olarak hesaplanması için yıl olarak bulunan değer 12 ile çarpıldı.

Verilerin istatistiksel analizleri için Statistical Package of Social Science 13.0 (SPSS) (Seri no: 10094113) paket programı kullanılarak yüzde, Ki-kare analizi, Mann Whitney U Testi, Tek Yönlü Varyans Analizi (ANOVA) ve beslenme öyküsünde belirlenen parametreler ile antropometrik ölçümler arasındaki ilişkiler için Spearman Korelasyon, Çoklu Regresyon analizleri kullanıldı.

\section{Bulgular ve Tartışma}

Araştırmaya katılan 417 çocuğun 199'u (\%47.7'si) kız, 218'i (\%52.3'u) erkek idi. Çalışma grubundaki çocukların aylara göre yaş ortalaması $61.24 \pm 11.08$ ay (min: 24 ay, max: 85 ay), cinsiyete göre yaş ortalaması ise kızlarda $62.25 \pm 10.52$ ay, erkeklerde $60.33 \pm 11.53$ ay idi. Grubun her iki cinsiyette de, 61-72 ay arasına yığıldığı tespit edildi (Tablo 1). 
Babaların yaş ortalaması 36.58 \pm 4.90 (min:25, max:53) olarak tespit edildi. Çalışmada, babaların $\% 54.5$ 'inin 32-38 yaş grubunda ve \%55.6'sının eğitim düzeylerinin üniversite eğitimi olduğu bulundu. Ayrıca babaların \%99.5'inin çalıştıkları tespit edildi (Tablo 1).

Annelerin yaş ortalaması 32.99 4.59 (min:23, max:46) idi. Çalışmada, annelerin \%49.0'ının 3035 yaş grubunda ve \%52.5'inin eğitim düzeylerinin üniversite eğitimi olduğu bulundu. Annelerin \%70.7'inin ev dışında çalışıyor olduğu tespit edildi (Tablo 1).

Saltık'ın (1990) çalışmasında da annelerin \%85'i çalışmakta idi (Saltık ve ark., 1990). Şanlıer ve Aytekin'in (2004) yaptığı çalışmadaki anne ve babaların genelde ortaokul ve lise mezunu (sırasıyla; \%46.2, \%48.9) olduğu annelerin \%77.5'inin ev hanımı olduğu belirlenmiştir (Şanlıer ve Aytekin, 2004). TNSA 2008 verilerine göre Türkiye'de kadınların yaklaşık beşte biri, eğitimi olmayan veya ilköğretimi tamamlamamış kadınlardır; kadınların yaklaşık \%52'si sadece ilköğretim birinci kademe eğitimini tamamlamışlardır. Kadınların dörtte biri, erkeklerin ise üçte biri lise ve üzeri eğitime sahiptir. Erkek nüfusun ortanca eğitim süresi 5.1 yll, kadınların ortanca eğitim süresi ise 4.5 yıldır. Edirne'de eğitim düzeyinin Türkiye ortalamasına göre yüksek olması (Türkiye Nüfus ve Sağlık Araştırması, 2008) bu durumun nedeni olabilir.

Ailelerin \%35.2'sinin aylık geliri, 1.001.00-2.000.00 TL arasında idi. Ailelerin aylık gelir ortalamas1, 2.433.40 \pm 2.136 .56 TL $(\min =400.00$ TL, $\max =30.000 .00$ TL) bulundu. Ailelerin \%99.3'ünün sağlık güvencesi olduğu tespit edildi ve \%89.7'i çekirdek aile tipinde idi (Tablo 1). Tanner'in (1976) bir çalışmasında belirttiği gibi, çocukların belirli yaşlarda gösterdikleri büyüme düzeyi, içinde bulundukları toplumun maddi ve moral koşullarını yansıtan bir aynadır (Tanner ve Whitehouse, 1976). Çalışma yaptığımız il Türkiye'nin ekonomik durumu iyi, sağlık hizmetlerinden yeterince faydalanabilen ve sağllk göstergelerinin üst düzeyde olduğu bir bölgesinde bulunmakta (www.ttb.org.tr) ve bu yüzden beslenme durumu sağlık düzeyi iyi olan bölgelerin durumunu yansitmaktadir.

Ebeveynlere göre kız çocuklarının \%49.7'sinin ve erkek çocuklarının \%49.5'inin iştah durumu orta olarak belirlendi. Kız ve erkek çocuklarının iştah durumları arasında anlamlı bir fark bulunmadı ( $>0.05)$ (Tablo 2). Saltık ve arkadaşlarının (1990) çalışmasında da anne babaya göre çocukların iştah durumları kızlar için \%54.2, erkek çocuklar için ise \%38.7 oranında bulunmuştur (Saltık ve ark., 1990). İştahsızlığın çocuklar için en önemli sonucu büyümelerinin olumsuz yönde etkilenmesidir. Çocukluk çağında iştahsızlık nedeniyle doktora başvuran normal çocukların oranı \%25-35 arasında değişmektedir (Wright ve Birks, 2000). Bu çalışmada kız ve erkek çocukların persentil eğrilerinin birbirine benzerlik göstermesi iştah durumlarının benzer olmasının sonucu olabilir.

Yüksek besinsel değerinin olması, ekonomik ve kontaminasyon riskinin düşük oluşu gibi birçok nedenden dolayı anne sütü alımının önemi bilinmektedir (Jason, 1991). TNSA 2008 verilerine göre ülkemizde emzirme çok yaygındır; çocukların \%97'si belirli sürelerle emzirilmişlerdir (12). Bu çalışmada anne sütü alma durumları değerlendirildiğinde kız çocuklarının \%94.0 ve erkek çocuklarının \%98.6'sının (min:0 ay, max:48 ay) anne sütü aldıkları bulundu. Anne sütü alan çocuklardan, erkek çocukların oranı kız çocuklarına göre daha yüksek idi $(\mathrm{p}<0.05)$. Erkek çocuklarının daha uzun süre anne sütü aldıkları tespit edildi (Tablo 2). Öncü'nün (2007) çalışmasında da katılımcılar arasında anne sütü alanların oranı \%97.9 idi (Öncü, 2007). Bu sonuç TNSA 2008 verileri ile benzerlik göstermekte idi (Türkiye Nüfus ve Sağlık Araştırması, 2008). Uğur ve arkadaşları da (1990) her yaş grubunda erkeklerin kızlara göre (aradaki fark anlamsız olsa da) daha fazla anne sütü aldığını saptamışlardır (Uğur ve ark., 1990). Son yıllarda yazılı ve görsel basında anne sütünün niteliğinin ve faydalarının anlatıldığı yayınların, bu konuda verilen eğitimlerin ve Bebek Dostu Hastanelerin sayısının artması (Ünsal ve ark., 2005), anne sütü verme oranının yükselmesinde etken olabileceğini düşündürmektedir. Bu çalışmada erkek çocuklarının daha uzun süre anne sütü almalarının nedeni Türkiye'de erkek çocuğuna verilen önemden kaynaklanıyor olabilir. 
Tablo 1. Araştırma grubunun ve ailelerin bazı sosyodemografik özellikleri $(n=417)$

\begin{tabular}{|c|c|c|c|}
\hline Özellikler & & $\mathbf{N}$ & $\%$ \\
\hline \multicolumn{4}{|l|}{ Kız Çocuklarının Yaş Grupları } \\
\hline $24-36$ ay & & 4 & 2.0 \\
\hline $37-48$ ay & & 12 & 6.0 \\
\hline $49-60$ ay & & 68 & 34.2 \\
\hline $61-72$ ay & & 80 & 40.2 \\
\hline $73-85$ ay & & 35 & 17.6 \\
\hline \multicolumn{4}{|l|}{ Erkek Cocuklarının Yas Grupları } \\
\hline $24-36$ ay & & 11 & 5.0 \\
\hline $37-48$ ay & & 18 & 8.3 \\
\hline $49-60$ ay & & 78 & 35.8 \\
\hline $61-72$ ay & & 83 & 38.1 \\
\hline $73-85$ ay & & 28 & 12.8 \\
\hline \multicolumn{4}{|c|}{$\begin{array}{ll}\text { Annelerin Yaş Ortalaması } \pm \mathbf{S S} & 32.99 \pm 4.59\end{array}$} \\
\hline \multicolumn{4}{|c|}{ Annelerin Yaş Grupları } \\
\hline $23-29$ & & 102 & 24.4 \\
\hline $30-35$ & & 204 & 49.0 \\
\hline $36-41$ & & 92 & 22.1 \\
\hline $42-47$ & & 19 & 4.5 \\
\hline \multicolumn{4}{|l|}{ Annelerin Eğitim Düzeyi } \\
\hline İlkokul & & 29 & 7.0 \\
\hline Ortaokul & & 18 & 4.3 \\
\hline Lise & & 151 & 36.2 \\
\hline Üniversite ve üstü & & 219 & 52.5 \\
\hline \multicolumn{4}{|l|}{ Annelerin İş Durumu } \\
\hline Çalışıyor & & 295 & 70.7 \\
\hline Ev hanımı & & 122 & 29.3 \\
\hline \multicolumn{4}{|c|}{ Babaların Yaş Ortalaması \pm SS $\quad 36.58 \pm 4.90$} \\
\hline \multicolumn{4}{|c|}{ Babaların Yaş Grupları } \\
\hline $25-31$ & & 55 & 13.1 \\
\hline $32-38$ & & 227 & 54.5 \\
\hline $39-45$ & & 117 & 28.2 \\
\hline $46-53$ & & 18 & 4.2 \\
\hline \multicolumn{4}{|l|}{ Babaların Eğitim Düzeyi } \\
\hline İlkokul & & 24 & 5.8 \\
\hline Ortaokul & & 25 & 6.0 \\
\hline Lise & & 136 & 32.6 \\
\hline Üniversite ve üstü & & 232 & 55.6 \\
\hline \multicolumn{4}{|l|}{ Babaların İş Durumu } \\
\hline Çalışıyor & & 415 & 99.5 \\
\hline İşsiz & & 2 & 0.5 \\
\hline \multicolumn{4}{|c|}{$\begin{array}{ll}y \text { Ayk Gelir Ortalaması } \pm \text { SS } & 2.433 \pm 2.136 \mathrm{TL} \\
\end{array}$} \\
\hline Aylık Gelir & & & \\
\hline$\leq 500 \mathrm{TL}$ & & 3 & 0.7 \\
\hline $501-1.000 . \mathrm{TL}$ & & 70 & 16.6 \\
\hline 1.001-2.000.TL & & 146 & 35.2 \\
\hline $2.001-3.000 \mathrm{TL}$ & & 119 & 28.6 \\
\hline$\geq 3.001 \mathrm{TL}$ & & 79 & 18.9 \\
\hline Sağlık-Sosyal Güvenceleri & & & \\
\hline Var & & $\begin{array}{c}414 \\
3\end{array}$ & $\begin{array}{c}99.3 \\
0.7\end{array}$ \\
\hline Yok & & & 0.7 \\
\hline Aile Tipi & & & \\
\hline Parçalanmış aile & & 7 & 1.7 \\
\hline Çekirdek aile & & 374 & 89.7 \\
\hline Geniş aile & & 36 & 8.6 \\
\hline
\end{tabular}

Günlük öğün sayısı değerlendirildiğinde k1z çocuklarının \%53.8'inin 3 öğünden az, erkek çocuklarının ise \%60.1'inin 3 öğünden fazla yemek yedikleri belirlendi. Erkek çocuklarının günlük ögün sayısı kız çocuklarına göre daha fazla idi $(p<0.05)$ (Tablo 2). İşveç’te Samuelson (1970), 
büyüme döneminde her gün düzenli olarak 3 ögün yemek yiyen çocuk oranının, sosyoekonomik düzeyle doğru orantılı olarak arttığını göstermiştir (Samuelson, 1970). Akgün'ün (1997) çalışmasında çalışma grubundaki öğrencilerin ancak \%73.7'si günde 3 öğün düzenli yemek yeme alışkanlığına sahip olduğu tespit edilmiştir (Akgün, 1997). Arlı ve arkadaşlarının (2006) yaptığı bir çalışmada, 3-6 yaş arası çocukların yaklaşık \%60'ında, günde 3 kezden fazla besin aldığı saptanmıştır (Arlı ve ark., 2006). Erkek çocuklarının fiziksel olarak daha hareketli olmaları, daha fazla kalori harcamaları, 3 öğünden fazla yemek yemelerinin nedeni olabilir.

Kız çocuklarının \%93.0'ının ve erkek çocuklarının \%87.6'sının düzenli kahvaltı yaptıkları bulundu ve aralarındaki fark anlamlı değildi (p>0.05) (Tablo 2). Akgün'ün (1997) çalışmasında da öğrencilerin büyük bir bölümü (\%88.1) her gün düzenli kahvaltı yaptıklarını ifade etmişlerdir (Akgün, 1997). Kahvaltı yapmak, büyüme dönemindeki çocuklarda günlük enerji ve besin gereksinimine katk1 sağlayarak büyümeyi olumlu yönde etkilemektedir.

Tablo 2. Anaokulu çocuklarının sağlık davranışlarının cinsiyete göre dağılımı (n=417)

\begin{tabular}{|c|c|c|c|c|c|c|c|}
\hline \multirow{2}{*}{ Özellikler } & \multicolumn{2}{|c|}{ Kız (n=199) } & \multicolumn{2}{|c|}{ Erkek (n=218) } & \multicolumn{2}{|c|}{ Toplam } & \multirow{2}{*}{$\mathbf{X}^{2}, \mathbf{p}$} \\
\hline & $\mathbf{N}$ & $\%$ & $\mathrm{n}$ & $\%$ & $\mathbf{n}$ & $\%$ & \\
\hline İştah Durumu & & & & & & & \\
\hline İyi & 75 & 37.7 & 82 & 37.6 & 157 & 37.6 & 0.008 \\
\hline Orta & 99 & 49.7 & 108 & 49.5 & 207 & 49.6 & 0.996 \\
\hline İştahsız & 25 & 12.6 & 28 & 12.8 & 53 & 12.7 & \\
\hline $\begin{array}{l}\text { Anne Sütü Alma } \\
\text { Durumu } \\
\text { Almad } 1 \\
\text { Ald } 1 \\
\end{array}$ & $\begin{array}{c}12 \\
187\end{array}$ & $\begin{array}{c}6.0 \\
94.0\end{array}$ & $\begin{array}{c}3 \\
215\end{array}$ & $\begin{array}{c}1.4 \\
98.6\end{array}$ & $\begin{array}{c}15 \\
402\end{array}$ & $\begin{array}{c}3.6 \\
96.4\end{array}$ & $\begin{array}{l}6.498 \\
0.011\end{array}$ \\
\hline $\begin{array}{l}\text { Günlük Ö̆ğün } \\
\text { Sayısı } \\
3 \text { öğünden az } \\
\text { yiyenler } \\
3 \text { öğünden fazla } \\
\text { yiyenler }\end{array}$ & $\begin{array}{c}107 \\
92\end{array}$ & $\begin{array}{l}53.8 \\
46.2\end{array}$ & $\begin{array}{c}87 \\
131\end{array}$ & $\begin{array}{l}39.9 \\
60.1\end{array}$ & $\begin{array}{r}194 \\
46.5\end{array}$ & $\begin{array}{l}223 \\
53.5\end{array}$ & $\begin{array}{l}8.033 \\
0.005\end{array}$ \\
\hline $\begin{array}{l}\text { Kahvaltı Yapma } \\
\text { Durumları } \\
\text { Yapmiyor } \\
\text { Yapıyor }\end{array}$ & $\begin{array}{c}14 \\
185\end{array}$ & $\begin{array}{c}7.0 \\
93.0\end{array}$ & $\begin{array}{c}27 \\
191\end{array}$ & $\begin{array}{l}12.4 \\
87.6\end{array}$ & $\begin{array}{c}41 \\
376\end{array}$ & $\begin{array}{c}9.8 \\
90.2\end{array}$ & $\begin{array}{l}3.359 \text {, } \\
0.067\end{array}$ \\
\hline $\begin{array}{l}\text { Günlük Uyku } \\
\text { Saatleri } \\
8 \text { saat } \\
9 \text { saat } \\
10 \text { saat } \\
11 \text { saat } \\
12 \text { saat }\end{array}$ & $\begin{array}{l}15 \\
55 \\
79 \\
33 \\
17\end{array}$ & $\begin{array}{c}7.5 \\
27.6 \\
39.7 \\
16.6 \\
8.5\end{array}$ & $\begin{array}{l}15 \\
50 \\
90 \\
37 \\
26\end{array}$ & $\begin{array}{c}6.9 \\
22.9 \\
41.3 \\
17.0 \\
11.9\end{array}$ & $\begin{array}{c}30 \\
105 \\
169 \\
70 \\
43\end{array}$ & $\begin{array}{c}7.2 \\
25.2 \\
40.5 \\
16.8 \\
10.3 \\
\end{array}$ & $\begin{array}{c}2.205 \\
0.698\end{array}$ \\
\hline
\end{tabular}

Kız çocuklarının \%39.7'sinin ve erkek çocuklarının \%41.3'ünün günde 10 saat uyudukları bulundu ve aralarındaki fark anlamlı değildi ( $\mathrm{p}>0.05$ ) (Tablo 2). Destekler biçimde bir araştırmasında Özbıçakçı (1998), yapılan birçok çalışmada çocukların \%60 oranında 9-10 saat gibi yeterli düzeyde uyuduklarını belirtmiştir (Özbıçakçı, 1998). Uykunun büyüme sürecinde önemli bir rolü vardır. Uyku döneminde salgılanan büyüme hormonunun çocuğun büyüme ve gelişiminde önemli bir rol üstlendiği ve uyku dönemi azalan çocukların büyümelerinde gecikme olduğu bilinmektedir. 
Anaokulu çocuklarında seçilmiş bazı parametreler iki cinste karşılaştırmalı olarak değerlendirildi. İki cins arasında doğum tartısı, doğum boyu ve ek gidaya başlama ayı arasındaki fark istatistiksel düzeyde anlamlı idi $(\mathrm{p}<0.05)$. Erkek çocuklarının doğum kilosu ve doğum boyu ortalamaları kız çocuklarına göre daha yüksek ve ek gıdaya başlama ayı daha ileri idi (Tablo 3).

Edirne'de merkez anaokullarında fizik antropometrik ölçümler ve beslenme parametreleri ile ilgili yapılan bir çalışmada (1990), doğum tartısı, ek gıdaya başlama ayı, emzirme süresi parametrelerinde erkek çocuklarının verilerinin daha iyi olduğu fakat istatistiksel düzeyde anlamlı olmadığı görülmüştür (Saltık ve ark., 1990). Kanalı ve arkadaşlarının (1994) bir çalışmasında, erkek çocuklarının doğum kilosu ve boyunun kız çocuklarına göre daha fazla olduğunu ifade etmişlerdir (Kanalı ve ark., 1994). Erkek çocuklarının doğum kilosu ve boyunun kız çocuklarına göre daha fazla olması cinsiyetin gelişim üzerine etkisinden kaynaklanıyor olabilir.

Aslan ve arkadaşlarının (2004), bir çalışmasında, erkek çocuklarına kız çocuklarından daha geç ek gıda verilmeye başlandığı bulunmuştur (Aslan ve ark., 2004). Bu çalışmada da erkek çocuklarına kız çocuklarına göre daha ileri ayda ek gıda verilmeye başlandığı bulundu (Tablo 3). Bu sonuç, çalışmadaki erkek çocuklarına daha uzun süre anne sütü verilmesinden dolayı ek gıdaya daha geç başlanılmış olabileceğini düşündürmektedir.

Tablo 3. Anaokulu çocuklarının cinsiyete göre beslenme ve antropometrik ölçümlerin karşılaştırmalı parametreleri $(n=417)$

\begin{tabular}{|c|c|c|c|c|}
\hline \multicolumn{2}{|r|}{ Değişkenler } & $\begin{array}{l}\text { Kizlar } \\
\mathrm{X} \pm \mathrm{SD}\end{array}$ & $\begin{array}{c}\text { Erkekler } \\
\mathrm{X} \pm \mathrm{SD}\end{array}$ & $\mathrm{U}^{*}, \mathrm{p}$ \\
\hline \multicolumn{2}{|c|}{ Doğum Ağırlı̆̆ 1 (gr) } & $3272 \pm 540$ & $3367 \pm 535$ & $2.167, \mathbf{0 . 0 3 0}$ \\
\hline \multicolumn{2}{|c|}{ Doğum boyu (cm) } & $50.3 \pm 3.1$ & $50.8 \pm 3.5$ & $2.113, \mathbf{0 . 0 3 5}$ \\
\hline \multirow{12}{*}{ 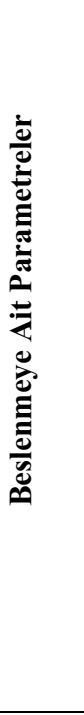 } & Emzirilme süresi/ay & $12.1 \pm 7.8$ & $13.5 \pm 8.1$ & $1.724,0.085$ \\
\hline & Sofraya oturma ayı & $12.3 \pm 7.2$ & $11.7 \pm 6.0$ & $0.399,0.690$ \\
\hline & Yürüme ay1 & $12.1 \pm 2.8$ & $12.0 \pm 2.3$ & $0.637,0.524$ \\
\hline & Ek gıda başlama ayı & $5.9 \pm 1.9$ & $5.7 \pm 1.3$ & $0.541,0.589$ \\
\hline & Süt-yoğurt başlama ayı & $6.6 \pm 2.7$ & $6.8 \pm 3.3$ & $0.060,0.953$ \\
\hline & Meyve suyu başlama ayı & $6.6 \pm 2.7$ & $6.5 \pm 2.5$ & $0.047,0.963$ \\
\hline & Et ürünleri başlama ayı & $9.7 \pm 3.8$ & $9.5 \pm 3.9$ & $1.097,0.273$ \\
\hline & Sebze-meyve püresi başlama ay 1 & $6.5 \pm 2.1$ & $6.2 \pm 1.5$ & $1.806,0.071$ \\
\hline & Yemek suyu başlama ayı & $6.4 \pm 1.4$ & $6.7 \pm 2.2$ & $2.078, \mathbf{0 . 0 3 8}$ \\
\hline & Yumurta sarısı başlama ayı & $7.4 \pm 2.9$ & $7.4 \pm 2.5$ & $0.152,0.879$ \\
\hline & Yumurta akı başlama ayı & $9.9 \pm 3.9$ & $9.5 \pm 3.4$ & $1.391,0.164$ \\
\hline & Haftada yenen yumurta/tane & $3.7 \pm 1.7$ & $4.1 \pm 2.0$ & $1.613,0.107$ \\
\hline \multirow{6}{*}{ 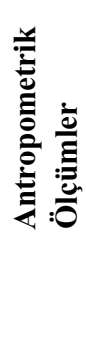 } & Boy $(\mathrm{cm})$ & $109.3 \pm 7.4$ & $109.1 \pm 8.1$ & $0.268,0.789$ \\
\hline & Ağırlık (kg) & $19.6 \pm 3.8$ & $20.1 \pm 4.7$ & $0.322,0.747$ \\
\hline & Diş sayısı & $20.4 \pm 1.5$ & $20.2 \pm 1.4$ & $1.777,0.076$ \\
\hline & ÜKOÇ† $\dagger(\mathrm{cm})$ & $16.79 \pm 1.6$ & $16.92 \pm 1.9$ & $0.345,0.730$ \\
\hline & TDDK $\dagger(\mathrm{mm})$ & $10.6 \pm 3.1$ & $10.3 \pm 3.2$ & $0.671,0.502$ \\
\hline & VKİ§ & $16.3 \pm 1.8$ & $16.7 \pm 2.2$ & $0.985,0.325$ \\
\hline
\end{tabular}

*Mann-Whitney U Testi; $†$ Üst Kol Orta Çevresi; $¥$ Triceps Deri Kıvrım Kalınlığı; $\S$ Vücut Kitle Indeksi. 
Araştırmaya katılan ailelerin aylık gelir düzeyleri TÜİK'in 2010 Şubat Ayı verilerine göre üç kategoriye ayrıldı (Açlık sınırı ve altında olanlar (842.98 TL ve altı geliri olan aileler), açlık ve yoksulluk sinırı arasında olanlar (842.99 TL ve 2.745.88 TL arasinda geliri olan aileler), yoksulluk sınırının üstünde olanlar (2.745.89 TL ve üzerinde geliri olan aileler) ) ve anaokulu çocuklarının antropometrik ölçümlerinin ailelerin aylık gelirine göre dağılımı değerlendirildi. Araştırma grubunun yoksulluk sınırının üstünde olan ailelerinde VKİ değerlerinin anlamlı olarak yüksek olduğu bulundu $(\mathrm{p}<0.05)$ (Tablo 4). Destekler biçimde Aksöz (2006), çalışmasında sosyo ekonomik düzeyin yüksek olduğu grupta VKİ anlamlı yüksek bulunmuştur (Aksöz, 2006). Şehla'da (2006) çalışmasında, orta ve yüksek gelir grubundaki çocukların tamamının antropometrik ölçümlerini, düşük gelir grubundaki çocukların antropometrik ölçümlerinden yüksek bulmuştur (Şehla, 2006). Özdemir ve arkadaşlarının (2005) çalışmasında aylık toplam gelirleri $250.00 \mathrm{TL}$ ve altında olan ailelerin çocuklarında 251.00 TL ve üzerinde olan ailelerin çocuklarına göre bodurluk daha yüksek oranlarda saptanmış ve bu farklar istatistiksel olarak da anlamlı bulunmuştur (Özdemir ve ark., 2005). Nedbigil ve arkadaşları (1997), Ankara'da farklı sosyoekonomik gruplardan çocuklar arasında ağırlık açısından anlamlı farklılıklar saptamışlardır (Nedbigil ve ark., 1997). Yurtdışında yapılan çalışmalarda da (1994) yüksek sosyoekonomik düzeyin büyüme gelişme sürecine olumlu etkisi görülmektedir. 1988 y1lında etnik grupta Martorell ve arkadaşlarının yaptıkları çalışmaları düşük sosyoekonomik düzeyin 2-11 yaş çocuklarının boy uzamasını etkilediği belirtilmektedir (Mertorell ve ark., 1994). Özyurt ve arkadaşlarının (2004) çalışmasında zayıflık ve bodurluk sosyoekonomik düzeyi düşük olan çocuklarda daha yüksek saptanmıştır (Özyurt ce ark., 2004). Süzek ve arkadaşlarının (2005) çalışmasında aile gelirinin çocuk obezitesi ile ilişkili olduğu belirlenmiştir (Suzek ve ark., 2005). Kırıkkale'de (2007) okul çocuklarında beslenme bozukluklarını saptamak amacıyla, sosyoekonomik yönden farklı iki okulda yürütülen bir çalışmada, iki okul arasında boy kısalığı sıklı̆̆ 1 açısından anlamlı fark bulunmamıştır (Dibek ve ark., 2007). Alp ve arkadaşlarının (1991) çalışmasında, gelir seviyesi arttıkça malnütrisyon görülme oranının azaldığ 1 ve ilişkinin önemli olduğu bulunmuştur (Alp ve ark., 1991). Bir çalışmada (2000), yüksek gelir düzeyi ile doğru orantılı olarak çocukların ulaşabildiği besin tüketim maddelerinin çokluğu ve çeşitliliğinin arttığı bildirilmektedir (Özenoğlu ve ark., 2000). Bu çalışmada, yoksulluk sınırının üstündeki ailelerde VKİ değerlerinin yüksek olması buna bağlı olabilir.

Tablo 4. Anaokulu çocuklarının antropometrik ölçümlerinin bazı değişkenlere göre dă̆ılımı $(n=417)$

\begin{tabular}{|c|c|c|c|c|c|c|}
\hline & \multirow{3}{*}{ Değişkenler } & \multicolumn{5}{|c|}{ Antopometrik Ölçümler } \\
\hline & & Ağırık (kg) & Boy (cm) & ÜKOÇ† $†(\mathrm{~cm})$ & TDKK $+(\mathrm{mm})$ & VKİ§̧ \\
\hline & & Ort \pm SD & Ort \pm SD & Ort \pm SD & Ort \pm SD & Ort \pm SD \\
\hline \multirow{4}{*}{ 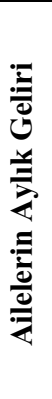 } & $\begin{array}{c}\text { Açlık Sınırı ve } \\
\text { Altında Olanlar } \\
(n=42)\end{array}$ & $19.7 \pm 4.7$ & $109.8 \pm 7.8$ & $16.5 \pm 1.8$ & $11.1 \pm 3.6$ & $16.2 \pm 2.2$ \\
\hline & $\begin{array}{c}\text { Açlık ve Yoksulluk } \\
\text { Sınırı Arasında } \\
\text { Olanlar (n=185) } \\
\end{array}$ & $19.5 \pm 3.8$ & $109.0 \pm 7.2$ & $16.7 \pm 1.6$ & $10.6 \pm 3.4$ & $16.3 \pm 1.8$ \\
\hline & $\begin{array}{c}\text { Yoksulluk } \\
\text { Sınırının Üstünde } \\
\text { Olanlar (n=190) }\end{array}$ & $20.3 \pm 4.7$ & $109.3 \pm 8.4$ & $17.0 \pm 1.9$ & $10.3 \pm 2.9$ & $16.5 \pm 2.1$ \\
\hline & $F^{*}, \mathbf{p}$ & $1.584,0.206$ & $0.163,0.849$ & $1.864,0.156$ & $1.396,0.249$ & $3.415,0.034$ \\
\hline
\end{tabular}

*Tek Yönlü Varyans Analizi (ANOVA); †Üst Kol Orta Çevresi; †Triceps Deri Kıvrım Kalınlı̆̆ı; §Vücut Kitle İndeksi.

Anaokulu çocuklarının antropometrik ölçümleri ve beslenme öyküleri arasında ikili korelasyon değerlerine bakıldığında, bu araştırmada güncel ağırlıkları fazla olan kız ve erkek çocuklarının boy, ÜKOÇ ve VKİ değerleri daha fazla bulundu $(\mathrm{p}<0.05)$ (Tablo 5). Boyları uzun olan kız çocuklarının ÜKOÇ değerleri, erkek çocuklarının ise hem ÜKOÇ ve VKİ değerleri artmakta idi $(p<0.05)$ (Tablo 5). Yaşı büyük olan kız ve erkek çocuklarının ağırlık, boy ve ÜKOÇ değerleri daha büyük idi $(p<0.05)$ (Tablo 5). 
Mayda'nın (1997) Sivas’ta ilköğretim öğrencilerinin antropometrik değerlendirme çalışmasında kol çevresi ve ağırlık arasındaki korelasyon yüksek, yaş ile korelasyon ise düşük bulunmuştur (Mayda, 1997). Bodur ve Uğuz (2007) bir ilköğretim okulunda VKİ'ni belirlemek amacı ile yürüttükleri bir çalışmada, çocukların yaşı ile birlikte VKİ değerlerindeki değişim her iki cinste benzer şekilde zayıf bir ilişki gösterirken (Bodur ve Uğuz, 2007), Bursa'da ilköğretim öğrencileri üzerinde yapılan çalışmada (2003), kız öğrencilerin yaşlarının artması ile birlikte aşırı ağırlıklı olma oranlarının da arttığ 1 , erkeklerde ise yaşın artmasıyla obezite oranının azaldığı gösterilmiştir (Akış ve ark., 2003). Gündem (1978), 0-60 ay çocuklarında ÜKOÇ ile boy ve tartı arasında ayrı ayrı güçlü sayılabilecek korelasyonlar saptamıştır (38). DSÖ raporunda belirtildiği gibi yaşla orantılı olarak boy ve kilo artmakta ve dolayısıyla VKİ değerleri de artmaktadır (World Health Organization Working Group, 1986).

Tablo 5. Anaokulu çocuklarının antropometrik ölçümleri ve bazı parametreler arasınd ikili korelasyon analizleri $(n=417)$

\begin{tabular}{|c|c|c|c|c|}
\hline \multirow{2}{*}{ Korrele Edilen Parametreler } & \multicolumn{2}{|l|}{ Kız $(n=199)$} & \multicolumn{2}{|c|}{ Erkek $(n=218)$} \\
\hline & $\mathbf{r}^{*}$ & $\mathbf{P}$ & $\mathbf{r}^{*}$ & $\mathbf{p}$ \\
\hline Boy/ Ağırlık & +0.79 & $<0.001$ & +0.86 & $<0.001$ \\
\hline Boy/ÜKOÇ $\dagger$ & +0.55 & $<0.001$ & +0.52 & $<0.001$ \\
\hline Boy/Emzirilme Süresi & -0.09 & 0.197 & -0.05 & 0.499 \\
\hline Boy/TDKK & -0.06 & 0.420 & -0.05 & 0.469 \\
\hline ÜKOÇ/Emzirilme Süresi & -0.00 & 0.933 & -0.03 & 0.614 \\
\hline ÜKOÇ/Yürüme ayı & +0.02 & 0.752 & -0.01 & 0.860 \\
\hline ÜKOÇ/TDKK & -0.03 & 0.672 & +0.04 & 0.559 \\
\hline Tart1/ÜKOÇ & +0.85 & $<0.001$ & +0.77 & $<0.001$ \\
\hline Tart1/Emzirilme Süresi & -0.09 & 0.230 & -0.04 & 0.547 \\
\hline Tart1/Yürüme ay1 & +0.04 & 0.568 & +0.01 & 0.962 \\
\hline Tart1/TDKK & -0.04 & 0.572 & -0.016 & 0.810 \\
\hline Yaş/Ağırlık & +0.55 & $<0.001$ & +0.56 & $<0.001$ \\
\hline Yaş/Boy & +0.76 & $<0.001$ & +0.74 & $<0.001$ \\
\hline Yaş/ÜKOÇ & +0.32 & $<0.001$ & +0.22 & 0.001 \\
\hline TDKK/Emzirilme Süresi & -0.07 & 0.302 & +0.01 & 0.891 \\
\hline TDKK/Yürüme ayı & +0.02 & 0.804 & +0.05 & 0.485 \\
\hline Yaş/TDKK & -0.07 & 0.338 & +0.05 & 0.440 \\
\hline Yaş/Yürüme ay1 & +0.00 & 0.994 & -0.02 & 0.812 \\
\hline Boy/Yürüme ayı & -0.06 & 0.374 & -0.05 & 0.957 \\
\hline Emzirilme süresi/Yürüme ay1 & -0.02 & 0.783 & -0.08 & 0.241 \\
\hline VKİ§/UKOÇ & +0.72 & $<0.001$ & +0.76 & $<0.001$ \\
\hline VKİ/Ağırlık & +0.64 & $<0.001$ & +0.57 & $<0.001$ \\
\hline VKİ/TDKK & +0.00 & 0.985 & +0.06 & 0.356 \\
\hline VKİ/Yaş & -0.04 & 0.555 & -0.06 & 0.361 \\
\hline VKİ/Emzirilme Süresi & -0.03 & 0.671 & -0.02 & 0.825 \\
\hline VKİ/Boy & +0.10 & 0.182 & +0.16 & $\mathbf{0 . 0 1 7}$ \\
\hline
\end{tabular}

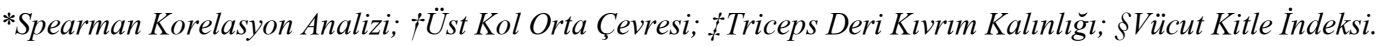

Büyümeyi değerlendirmede en sık kullanılan antropometrik ölçümler, vücut ağırlığı, boy uzunluğu, baş çevresi, ÜKOÇ, deri kıvrım kalınlığı ve vücut kısımlarının birbirine oranlarıdır (Krdoğlu, 1993). Anaokuluna devam eden çocukların cinsiyete göre ağırlık ve boy değerleri ile beslenme parametreleri arasında çoklu regresyon analizi yapıldı. Buna göre doğum boyları daha fazla günlük uyku saatleri daha az olan erkek çocuklarının güncel ağıllıklarının daha yüksek olduğu saptandı $(\mathrm{p}<0.05)$ (Tablo 6). Düşük doğum ağırlığı ve doğum boyu erken çocukluk döneminde boya göre ağırlığın düşük olması ile ilişkili olabilmektedir (Gorstein, 1994). Ayrıca Yıldırım uyuyamayan çocuklarda obezite tehlikesinin bulunduğunu belirtmiştir (www.memorial.com.tr). 
Çalışmada, doğum ağırlığı fazla olan, ek gıdaya daha geç başlayıp anne sütünü daha fazla alan kız çocuklarının güncel ağırlıklarının daha fazla olduğu bulundu $(\mathrm{p}<0.05)$ (Tablo 6). Literatürde belirtildiği gibi çocuğun doğum ağırlığı büyümesini etkiler (Kurdoğlu, 1993). Uğur ve arkadaşlarının (1990) bir çalışmasında güncel ağırlıkları az olan çocukların doğum kilolarının da düşük olduğunu saptanmıştır (Uğur ve ark., 1990). Ayrıca araştırmada güncel ağırlığı fazla olan kız çocuklarının günlük uyku saatlerinin daha az olduğu saptandı $(\mathrm{p}<0.05)$ (Tablo 6). Yıldırım, yeterince uyuyamayan çocuklarda obezite ve depresyon tehlikesinin bulunduğunu belirtmiştir. Bunun nedeninin bu çocuklarda abur cubur yeme, fazla kalorili içecekler içme ve televizyon ya da bilgisayar karşısında geçirilen sürenin daha fazla olması olduğunu ifade etmiştir (www.memorial.com.tr).

Doğum boyları fazla olan, daha geç ek gıdaya başlayıp daha uzun süre anne sütü alan erkek çocuklarının güncel boylarının daha uzun olduğu gözlendi $(p<0.05)$ (Tablo 6). Seçkin ve arkadaşlarının (2008) bebeklikte büyüme durumunu etkileyen etmenleri saptamak için yaptıkları bir çalışmada da zayıflığın ve bodurluğun anne sütü 6 aydan az verilen bebeklerde daha yüksek oranda olduğu görülmüştür (Seçkin ve ark., 2008).

Tablo 6. Anaokulu çocuklarının cinsiyete göre ă̆ırlıkları ve boyları ile etkileyen parametreler arasında çoklu regresyon ilişkileri $(n=417)$

\begin{tabular}{|c|c|c|c|c|c|c|c|}
\hline \multirow{2}{*}{\multicolumn{2}{|c|}{ Parametreler }} & \multicolumn{3}{|c|}{ Erkek $(n=218)$} & \multicolumn{3}{|c|}{ Kuz (n=199) } \\
\hline & & $\beta$ & $\mathbf{T}$ & $\mathbf{P}$ & B & $\mathbf{T}$ & $\mathbf{p}$ \\
\hline \multirow{16}{*}{$\begin{array}{l}\text { Ağırlı̆̆ı } \\
\text { etkileyen } \\
\text { parametreler }\end{array}$} & Sabit & 14.956 & 2.531 & 0.012 & 18.938 & 3.311 & 0.001 \\
\hline & Yumurta akı yemeye başlanılan ay & -0.109 & -1.110 & 0.268 & -0.051 & -0.612 & 0.542 \\
\hline & Yumurta sarısı yemeye başlanılan ay & 0.164 & 1.116 & 0.266 & 0.045 & 0.325 & 0.746 \\
\hline & Yemek suyu yemeye başlanılan ay & 0.324 & 1.108 & 0.269 & -0.261 & -1.270 & 0.206 \\
\hline & Sebze püresi yemeye başlanılan ay & -0.266 & -0.865 & 0.388 & 0.236 & 1.148 & 0.253 \\
\hline & Et ve et ürünleri yemeye başlanılan ay & -0.017 & -0.201 & 0.841 & -0.061 & -0.712 & 0.477 \\
\hline & Meyve suyu yemeye başlanılan ay & -0.006 & -0.048 & 0.961 & 0.068 & 0.583 & 0.561 \\
\hline & Yoğurt yemeye başlanılan ay & 0.007 & 0.072 & 0.943 & -0.016 & -0.123 & 0.902 \\
\hline & Ek gıdaya başlama ayı & -0.014 & -0.052 & 0.959 & 0.532 & 2.251 & 0.026 \\
\hline & Anne sütü alma süresi (ay) & -0.044 & -1.124 & 0.262 & -0.064 & -1.837 & 0.068 \\
\hline & Doğum ağırlığ1 & 0.000 & -0.817 & 0.415 & 0.001 & 2.276 & 0.024 \\
\hline & Günlük öğün sayısı & 0.742 & 1.825 & 0.069 & -0.080 & -0.253 & 0.800 \\
\hline & Ailenin aylık geliri & 0.000 & 1.526 & 0.128 & $-3.859 \mathrm{E}-6$ & -0.031 & 0.975 \\
\hline & Günlük uyku saati & -1.607 & -5.662 & $<0.001$ & -0.683 & -2.628 & 0.009 \\
\hline & Doğum boyu & 0.386 & 3.830 & $<0.001$ & 0.044 & 0.381 & 0.704 \\
\hline & \multicolumn{7}{|c|}{ (Anaokulu Erkek Çocuklarında $\left.R=0.480, R^{2}=0.230\right)$, (Anaokulu Klz Çocuklarında $R=0.455, R^{2}=0.207$ ) } \\
\hline \multirow{15}{*}{$\begin{array}{l}\text { Boyları } \\
\text { etkileyen } \\
\text { parametreler }\end{array}$} & Sabit & 109.628 & 10.785 & $<0.001$ & 111.643 & 10.082 & 0.001 \\
\hline & Yumurta akı yemeye başlanılan ay & -0.356 & -2.107 & 0.036 & -0.038 & -0.234 & 0.815 \\
\hline & Yumurta sarısı yemeye başlanılan ay & 0.356 & 1.410 & 0.160 & -0.009 & -0.035 & 0.972 \\
\hline & Yemek suyu yemeye başlanılan ay & 0.796 & 1.584 & 0.115 & -0.417 & -1.051 & 0.295 \\
\hline & Sebze püresi yemeye başlanılan ay & -0.537 & -1.017 & 0.311 & 0.504 & 1.266 & 0.207 \\
\hline & Et ve et ürünleri yemeye başlanılan ay & 0.158 & 1.061 & 0.290 & -0.216 & -1.310 & 0.192 \\
\hline & Meyve suyu yemeye başlanılan ay & -0.111 & -0.488 & 0.626 & -0.124 & -0.551 & 0.582 \\
\hline & Yoğurt yemeye başlanılan ay & -0.113 & -0.672 & 0.502 & 0.062 & 0.248 & 0.805 \\
\hline & Ek gıdaya başlama ayı & -0.146 & -0.313 & 0.755 & 0.536 & 1.173 & 0.242 \\
\hline & Anne sütü alma süresi (ay) & -0.025 & -0.377 & 0.707 & -0.067 & -0.989 & 0.324 \\
\hline & Doğum ağırlığı & 0.000 & -0.425 & 0.672 & 0.002 & 1.565 & 0.119 \\
\hline & Günlük öğün sayısı & 0.671 & 0.960 & 0.338 & -1.047 & -1.722 & 0.087 \\
\hline & Ailenin aylık geliri & 0.000 & 1.606 & 0.110 & 0.000 & 0.634 & 0.527 \\
\hline & Doğum boyu & 0.535 & 3.082 & 0.002 & 0.259 & 1.157 & 0.249 \\
\hline & \multicolumn{7}{|c|}{ (Anaokulu Erkek Çocuklarında $R=0.474, R^{2}=0.224$ ) } \\
\hline
\end{tabular}


Neyzi ve arkadaşlarının 2008 yılında güncelledikleri, Türk çocuklarının büyüme ve gelişmelerini değerlendirmek için geliştirdikleri referans değerler ile anaokulu çocuklarının durumu irdelendi. Buna göre kız çocuklarının \%48.2'sinin, erkek çocuklarının ise \%50.9'unun boy değerlerinin ilk persentil çeyrekliğine yığıldığı görüldü (Tablo 7). Şanlıer ve Aytekin'in (2004) 0-36 ay arasındaki çocuklarda yaptıkları çalışmada 31-36 aylık olan erkek çocuklarının \%50.0'sinin, kız çocuklarının ise \%66.6'sının boy uzunluğu beş ve daha alt persentilde olduğu tespit edilmiştir (Şanlıer ve Aytekin, 2004). Çakmakoğlu ve arkadaşlarının (1999) Narlıdere'de 663 çocuk ile gerçekleştirdikleri çalışmalarında, NCHS'ye göre \%4.1 oranda çocukta yaşa göre boyda kısalık (bodurluk) saptanmıştır (Çakmakoğlu ve ark., 1999). Açkurt ve Wetherilt'in (1991) Türkiye'nin üç coğrafi bölgesinde 7-17 yaş grubu 960 çocukla yaptıkları çalışmada ise; erkeklerin \%53-72'si boy, \%40-63'ü ağırlık, kızların \%50-71'i boy, \%20-63'ü ağırlık bakımından NCHS'ye göre 50. persentilin altında bulunmuştur (Ackurt ve Wetherit, 1991).

Ağırlık değerlerinde, kız çocuklarının \%31.7'sinin 25. ve 50. persentil dilimlerinde, erkek çocuklarının ise \%28.4'ünün 25. persentil ve altında idi (Tablo 7). Şamşul'un (1989) 1-3 yaş grubu çocukların büyüme gelişmelerini değerlendirmek üzere yaptığı bir çalışmada 25.-50. persentil diliminde ağıllık sahibi olan çocuklar \%75.3 olarak bulunmuştur (Şamşul, 1989). Erkan ve arkadaşlarının (2007) çalışmasında çocukların \%10'unun ağırlığı 90. ve 97. persentil dilimleri arasında tespit edilmiştir (Erkan ve ark., 2007).

VKİ için kullanılan referans değerleri ülkeler arasında farklılık gösterdiği gibi bir ülkenin farklı bölgelerinde, hatta aynı bölgede yaşayan değişik ırklarda bile farklılıklar göstermektedir. Bu nedenle VKİ ile beslenme durumu değerlendirilirken çocuğun yaşadığı bölge için belirlenen standart VKİ persentillerine göre değerlendirilmesi daha uygun olacaktır. Ülkemizde ise bu konuda çalışmalar olmakla birlikte Marmara Bölgesi çocukları için geliştirilmiş standart değerleri gösterir çalışmalar oldukça sınırlı sayıdadır (Babaoğlu ve Hatun, 2002; Zimmet, 2000; Adıyaman ve ark., 2002).

VKİ için 10.-75. persentil değerleri arası normal sınırlar olarak kabul edilmektedir. VKİ'nin üst değerleri olan 85. ve 95. persentiller klinik önem taşımaktadır. Her yaş dilimi için VKİ değerinin 95. persentil ve üzeri dilimin içinde olanlar obes, 85-95. persentil dilim içinde olanlar obesite için yüksek risk grubu (aşırı kilolu, overweight) olarak değerlendirilmektedir (Donohoue, 2004). Ece ve arkadaşlarının (2004) bir çalışmasında çocukların VKİ hesaplandığında, çocukların \%2.1'i fazla kilolu, \%0.9'u obez bulunmuştur (Ece ve ark., 2004). Bu çalışmada çocukların VKİ değerlerinin her iki cinsin 1/3'ünden fazlasında 75. persentil ve üzerinde olduğu bulundu (Tablo 7). Buna göre çalışma grubunun normal persentil dilimlerine göre dağılım gösterdiği söylenebilir.

Tablo7. Anaokulu çocuklarının cinsiyete göre ă̆ırlık, boy ve vücut kitle indeksi değerlerinin persentil dilimlerine göre dă̆ılımı $(n=417)$

\begin{tabular}{|c|c|c|c|c|c|c|c|c|c|c|c|c|c|c|c|c|c|c|}
\hline \multirow{3}{*}{$\begin{array}{l}\text { Persentil } \\
\text { Dilimleri }\end{array}$} & \multicolumn{6}{|c|}{ Kız (n=199) } & \multicolumn{6}{|c|}{ Erkek $(n=218)$} & \multicolumn{6}{|c|}{ Toplam } \\
\hline & \multicolumn{2}{|c|}{ A ğırlık } & \multicolumn{2}{|c|}{ Boy } & \multicolumn{2}{|c|}{ VKI* } & \multicolumn{2}{|c|}{ Ağırlık } & \multicolumn{2}{|c|}{ Boy } & \multicolumn{2}{|c|}{ VKİ } & \multicolumn{2}{|c|}{ Ağırlık } & \multicolumn{2}{|c|}{ Boy } & \multicolumn{2}{|c|}{ VKİ } \\
\hline & $\mathrm{n}$ & $\%$ & $\mathrm{~N}$ & $\%$ & $\mathrm{n}$ & $\%$ & $\mathrm{n}$ & $\%$ & $\mathrm{n}$ & $\%$ & $\mathrm{n}$ & $\%$ & $\mathrm{~N}$ & $\%$ & $\mathrm{~N}$ & $\%$ & $\mathrm{n}$ & $\%$ \\
\hline$<25$ & 53 & 26.6 & 96 & 48.2 & 50 & 25.1 & 62 & 28.4 & 111 & 50.9 & 48 & 22.0 & 115 & 27.6 & 207 & 49.6 & 98 & 23.5 \\
\hline $26-50$ & 63 & 31.7 & 48 & 24.1 & 38 & 19.1 & 47 & 21.6 & 39 & 17.9 & 42 & 19.3 & 110 & 26.4 & 87 & 20.9 & 80 & 19.2 \\
\hline $51-75$ & 41 & 20.6 & 26 & 13.1 & 43 & 21.6 & 50 & 22.9 & 43 & 19.7 & 53 & 24.3 & 91 & 21.8 & 69 & 16.5 & 96 & 23.0 \\
\hline $76<$ & 42 & 21.1 & 29 & 14.6 & 68 & 34.2 & 59 & 27.1 & 25 & 11.5 & 75 & 34.4 & 101 & 24.2 & 54 & 12.9 & 143 & 34.3 \\
\hline
\end{tabular}

*Vücut Kitle Indeksi 


\section{Sonuç ve Öneriler}

Çocukların beslenmesinde hafif ve orta dereceli beslenme yetersizliklerinin dikkatli bir şekilde izlenmesi ve gerekli düzeltmelerin yapılması sağlıklı nesiller yetiştirmek açısından önem taşımaktadır (Akgün, 1997). Çalışma grubundaki olguların sosyo-ekonomik durumları yüksekti. Dolayısıyla beslenme öyküleri de dahil olmak üzere tüm değişkenler olumlu bir görünüm sergilemektedir.

Çocukların büyüme ve gelişmelerini etkileyen etmenlerin belirlenmesine yönelik çalışmaların arttırılarak ülkemize özgü persentil dilimlerinin kullanılması önemlidir. Ülkemizde sosyo ekonomik şartların bölgesel olarak farklılık göstermesi her bölgeye özel persentil dilimlerinin belirlenmesini gerektirmektedir. Buna yönelik belirli aralıklarla ve daha geniş bir çerçevede çalışmalar yapılmalıdır.

Anne sütünün önemi artık dünyaca kabul görmüş bir gerçektir. DSÖ çocukların 24 aya kadar emzirilmesini önermektedir. Anne ve bebekle ilk iletişimi kuran hemşireler, bebeklerin erken emzirilmelerinin sağlanması, emzirme teknikleri ve anne sütü hakkında anne ve yakınlarının eğitilmesi konularında hassasiyetle durmalıdırlar.

Anne sütünün 12. aydan sonra besleyicilik değeri azalmakta ve çocuğun gereksinimlerini karşılayamamaktadır. Bu dönemde anne sütünün uygun ek gıdalarla beraber verilmesinin önemi eğitim programlarında yer almalıdır.

Okul öncesi dönemde ara öğünlerde alınan gıda maddelerinin niteliği önem kazanmaktadır. Bu nedenle ara öğünlerde çocuklara verilen gida maddelerinin besin değeri yüksek olan gidalardan seçilmesi oldukça önemlidir. Uygunsuz yeme davranışları gelişiminin önlenmesi amacıyla okul öncesi eğitim kurumlarında düzenli öğün zamanları oluşturulması ve planlı ara öğünler dışında atıştırmaya izin verilmemesinin önemi üzerinde durulmalıdır. Ayrıca araştırmadan çıkan sonuç doğrultusunda, doğum öncesi bakım hizmetlerinin içinde, gebelik süresince annenin beslenmesine yönelik verilecek eğitim programları üzerinde hemşirenin titizlikle durması gerekmektedir. Güncel ağırlık ve boy değerlerinin bebeğin doğum ağırlığı ve boyu ile ilişkisi bunun önemini vurgulamaktadır.

\section{Teşekkür}

Bu çalışmaya, 2009/02 nol'lu proje kapsaminda destek veren Trakya Üniversitesi Bilimsel Araştırma Projeler Birimi (TÜBAP)'ne teşekkür ediyoruz.

\section{Kaynaklar}

Ackurt F., Wetherit H. 1991. Türk Okul Çağı Çocuklarının Büyüme Gelişme Durumlarının Amerikan Normlarına Göre Değerlendirilmesi. Beslenme ve Diyet Dergisi.20(1):21-34.

Adıyaman P., Ocal G., Berberoğlu M. ve ark. 2002. Hyperinsulinism And Dyslipidemia İn Glucose Tolerant And İntolerant Obese Children. 41 st Annual Meeting of the European Society for Pediatric Endocrinology. s.25-28.

Akgün S. 1997. Sosyo-Ekonomik Yönden Farklı İki İlkokul Öğrencilerinin Fizik Büyüme Durumları ve Etkileyen Bazı Faktörlerin Araştırılması (Yüksek Lisans Tezi). Hacettepe Üniversitesi Sağlık Bilimleri Enstitüsü. Ankara.

Akış N., Pala K., İrgil E., ve ark. 2003. Bursa İli Orhangazi İlçesi 6 Merkez İlköğretim Okulunda 6-14 Yaş Grubu Öğrencilerde Kilo Fazlalığı ve Obezite. Uludağ Üniversitesi Tıp Fakültesi Dergisi. 29:17-20.

Aksoz Bilici E. 2006. 6-16 Yaş Okula Giden Çocuklarda Beslenme Alışkanlıklarının Büyüme Gelişme ve Obezite Üzerine Etkileri (tez). Ankara: Ankara Tip Fakültesi.

Alp H., Altınkaynak S., Kurkcuoğlu M. 1991. 0-24 Aylık Çocuklarda Malnutrisyon Prevalansı ve Etkileyen Faktörler. Aile ve Toplum. 3:41-47.

Arlı M., Şanlıer N., Küçükkömürler S., Yaman M. 2006. Anne ve Bebek Beslenmesi. Ankara: Cantekin Matbaas1, 56-59. 
Aslan D., Ozcebe H., Bilir N., ve ark. 2004. Van İli Kent Merkezinde Beş Yaş Altı Çocuklarda Beslenme Ve Malnütrisyon Durumu. Çocuk Sağllğı Dergisi. 4(1):16-23.

Babaoğlu K., Hatun Ş. 2002. Çocukluk Çağında Obezite. Surekli Tıp Eğitim Dergisi.11:8-10.

Behrman R.E., Kliegmen R.M. 2001. Nelson Essentials of Pediatrics. (Çeviri: M. Tuzcu), İstanbul: Nobel Tıp Kitapevleri, 3:1-55.

Bertan M., Güler Ç. 1997. Halk Sağlı̆̆ı Temel Bilgiler. Ankara: Güneş Yayınevi, 210-225.

Bodur S., Uğuz M. 2007. 11-15 Yaş Çocuklarda Vücut Yağ Yüzdesinin Beden Kitle İndeksi ve Biyoelektriksel İmpedans Analizi İle Değerlendirilmesi. Genel Tıp Dergisi.17(1):21-27.

Cakmakoğlu B., Ozgener N., Unal Aslan B., ve ark. 1999. Narlıdere İlçesindeki İlkokul Birinci Sınıf Öğrencilerinin Büyümelerinin Değerlendirilmesi. Ege Tıp Dergisi.38(3):149-152.

Çocuklarda Uykunun Önemi. Erişim:www.memorial.com.tr/ Erişim Tarihi: 02 Haziran 2010.

Çoşkun T., Aysun S. 2003. Çocuk Sağlığı. Ankara: Alp Ofset, 41-66.

Dibek Mısırlığlu E., Cakır B, Albayrak M, ve ark. 2007. Okul Çocuklarında Beslenme Bozuklukları: Boy Kısalığı ve Obezite. KÜ Tıp Fakültesi Dergisi.9(1):7-10.

Donohoue P.A. 2004. Obesity. In: Behrman RE, Kliegman RM, Jenson BE (eds). Nelson Textbook of Pediatrics (17th ed). Philadelphia: WB Saunders, s.173-177.

Ece A., Ceylan A., Gurkan F., ve ark. 2004. Diyarbakır ve Çevresi Okul Çocuklarında Boy Kısalığı, Düşük Ağırlık ve Obesite Sıklığı. Van Tıp Dergisi.11(4):128-136.

Ercan O. 2003. Büyümenin İzlenmesi, İ.Ü.Cerrahpaşa Tıp Fakültesi Sürekli Tip Eğitimi Etkinlikleri. Sağlam Çocuk İzlemi Sempozyum Dizisi No:35, İstanbul: 21-26.

Erkan T., Yalvaç S., Erginöz E., ve ark. 2007. İstanbul Üniversitesi Cerrahpaşa Tıp Fakültesi Çocuk Yuvası'ndaki Çocukların Beslenme Durumlarının Antropometrik Ölçümlerle Değerlendirilmesi. Türk Pediatri Arşivi. 42:142-7.

Evliyaoğlu N. 2007. Sağlam Çocuk İzlemi. Türk Pediatri Arşivi. 42 (Özel Sayı): 6-10.

Gorstein J., Sullivan K, Yip R, et al. 1994. Issues in The Assessment of Nutritional Status Anthropometry. Bulletin of the World Health Organization.72:27-38

Gündem G. 1978. 0-60 Ay Yaş Grubu Çocuklarda Üst Kol Orta Çevresi Ölçülerek Beslenme Durumunun Saptanması (Yüksek Lisans Tezi). Ankara: Hacettepe Üniversitesi.

Jason J. 1991. Breast-Feeding in 1991. N Engl J Med. 325:1036-1037.

Kanalı S., Onvural A., Erten O. 1994. Doğum Kilosunu Etkileyen Faktörler. Perinatoloji Dergisi. 2:89-93.

Kentlerde Sağlik Hizmetleri2.pdf. Erişim: www.ttb.org.tr/kutuphane/Erişim Tarihi: 16 Mayıs 2010.

Kurdoğlu G. 1993. Beslenme Durumunun Değerlendirilmesi. Neyzi O, Ertuğrul T (Editorler). Pediatri. İstanbul, Nobel Tip Kitabevi, s.395-410.

Martorell R., ve ark. 1994. Body Proportions in Three Ethnic Groups. Children and Youths 2-17 Years in NHANES and NHANESI. Human Biology. 60:205.

Mayda A.S. 1997. Sivas İl Merkezindeki İlkokul Çocuklarında Antropometrik Değerlendirme Çalışması (Uzmanlık Tezi). Sivas:Cumhuriyet Üniversitesi Tıp Fakültesi.

Nedbigil İ., Hizel S., Tanyer G., ve ark. 1997. Heights and Weights of Primary School Children of Different Social Beckgraund in Ankara, Turkey. J Trop Pediatr. 43:297.

Neyzi 0. 2002. Büyüme ve Gelişmenin Değerlendirilmesi, Pediatri. Ankara: Nobel Tip Kitabevi, 79-200.

Ozenoğlu A., Sabuncu T., Unuvar E. 2000. Ekzojen Obesitesi Olan Adolesanların Günlük Diyetlerinde Aldıkları Enerji Ve Besin Öğelerinin Dağılımı. Endokrinolojide Yönelişler. 9(1):38-43.

Ozyurt B.C., Dinc G., Eser E. ve ark. 2004. Manisa'da Okul Cağı Çocuklarının Büyüme Gelişme Durumlarının Saptanması. 9. Ulusal Halk Sağlığı Kongresi Bildiri Özet Kitabı. Ankara, s.40. 
Öncü Ü. 2007. 1-5 Yaş Arası Çocukların Persentillerine Ailenin Sosyoekonomik Düzeyinin ve Annenin Beslenme Konusundaki Bilgisinin Etkisi (Uzmanlık Tezi). İstanbul: Taksim Eğitim ve Araştırma Hastanesi Aile Hekimliği.

Özbıçakçı Ş. ve ark. 199). Okul Sağlığı Hemşireliğine Yönelik Pilot Bir Çalışma. Uluslararası Katılımlı 6. Ulusal Hemşirelik Kongresi. Ankara.

Özdemir O., Ercevik E., Calışkan D. 2005. Farklı Sosyoekonomik Düzeye Sahip İki İlköğretim Okulunda Öğrencilerin Büyümelerinin Değerlendirilmesi. Ankara Üniversitesi Tıp Fakültesi Mecmuası. 58:23-29.

Pekcan G. 1984. İlkokul Çocuklarında Demir Yetersizliği Anemisi, Enfeksiyon ve Okul Başarısı Arasındaki Etkileşimler Üzerine Bir Araştırma, Beslenme ve Diyet Dergisi. 13(1):51-56.

Report of WHO Expert Comitte 1995. Physical Status: The Use and Interpretation of Anthropometry. Geneva.

Saltık A., Keleş F, Yorulmaz F, Dindar i, Turan N. 1990. Edirne Merkez Anaokullarında Fizik Antropometrik Ölçümler ve İlgili Beslenme Parametreleri. Beslenme ve Diyet Dergisi. 9(1):43-60.

Samuelson G. 1970. An Epidemiological Study of Childh Health and Nutyrition in A Northern Swedish Country. Nutr Metab. 12:321.

Seckin R., Utku M., Bingol S. 2008. Bebeklikte Büyüme Durumu ve Etkileyen Bazı Sosyodemografik Etmenler. Sted.17(7):111.

Suzek H., Arı Z., Uyanık B. 2005. Muğla'da Yaşayan 6-15 Yaş Okul Çocuklarında Kilo Fazlalığı ve Obezite Prevalans1. Turk Biyokimya Dergisi.30(4):290-295.

Şamşul N. 1989. 1-3 Yaş Grubu Eskişehir İli Sivrihisar İlçesi Çocuklarının Büyüme-Gelişme Beslenme Durumları ve Bu Durumu Etkileyen Faktörlerin Saptanması (Yüksek Lisans Tezi). İstanbul, İstanbul Üniversitesi Çocuk Sağlığı Enstitüsü.

Şanlıer N., Aytekin F. 2004. Ankara'da Yaşayan 0-36 Ay Çocukların Bazı Antropometrik Ölcümleri ve Anne Sütü İle Beslenme Durumlarının Saptanması. GU Gazi Eğitim Fakültesi Dergisi.24(1):271-289.

Şanlıer N., Aytekin F. 2004. Sıfır-Üç Yaş Grubunda Çocuğu Bulunana Annelerin Beslenme ve İshal Konusunda Bilgi Ve Davranışlarının İncelenmesi. Gazi Üniversitesi Gazi Eğitim Fakültesi Dergisi. 24(3):81-100.

Şehla İ. (2006). 9-72 Aylık Çocuklarda Antropometrik Ölçümler ve Antropometrik Ölçümlere Etki Eden Parametrelerin Araştırılması (Uzmanlık Tezi). İstanbul: Bakırköy Dr. Sadi Konuk Eğitim ve Araştırma Hastanesi

Tanner J.M., Whitehouse R.H. 1976. Clinical Longitudinal Standards for Height, Weight, Height Velocity, Weight Velocity and Stages of Puberty. Arch Dis Child. 51:170-9.

Türkiye Nüfus ve Sağlık Araştırması. 2008. Erişim: www.hips.hacettepe.edu.tr/tnsa2008/ Erişim Tarihi: 10.05.2010.

Uğur S., Telci A., Bulut A., ve ark. 1990) 0-2 Yaş Grubunda Beslenme Durumunun Değerlendirilmesi. İstanbul Üniversitesi Dergisi. 53(1).

Ünsal H, Atlıhan F, Özkan H, ve ark. 2005. Toplumda Anne Sütü Verme Eğilimi ve Etki Eden Faktörler. Çocuk Sağlığı ve Hastalıkları Dergisi. 48:226-233.

World Health Organization Working Group. 1986. Use and Interpretation of Anthropometric Indicators of Nutritional Status. Bulletin of the World Health Organization. 64:929-941.

Wright C., Birks E. 2000. Risk Factors for Failure to Thrive: A Population-Based Survey. Child Care Health Dev. 26: 5-16.

Zimmet P. 2000. The Global Scope Of Diabetes And Obesite-An Epidemic in Progress: Paradise Lost. 60th Scientific Sessions of the American Diabetes Associations. 6:1-10. 